\title{
EquiLIBRIUM
}

Quarterly Journal of Economics and Economic Policy

2015 VOLUME 10 ISSUE 3, September

p-ISSN 1689-765X, e-ISSN 2353-3293

www.economic-policy.pl

Tura, K. \& Szyszko, M. (2015). Can Inflation Forecast and Monetary Policy Path be Really Useful? The Case of the Czech Republic. Equilibrium. Quarterly Journal of Economics and Economic Policy, 10(3), pp. 9-26, DOI: http://dx.doi.org/10.12775/ EQUIL.2015.022

Magdalena Szyszko*

WSB University in Poznań, Poland

Karolina Tura

Gdańsk University of Technology, Poland

\section{Can Inflation Forecast and Monetary Policy Path be Really Useful? The Case of the Czech Republic**}

JEL Classification: E52; E58; E61

Keywords: inflation forecasts; inflation forecast targeting; policy path; inflation expectations

\begin{abstract}
Producing and revealing inflation forecast is believed to be the best way of implementing a forward-looking monetary policy. The article focuses on inflation forecast targeting (IFT) at the Czech National Bank (CNB) in terms of its efficiency in shaping consumers' inflation expectations. The goal of the study is to verify the accuracy of the inflation forecasts, and their influence on inflation expectations. The research is divided into four stages. At the first stage, central bank credibility is examined. At the second stage - accuracy of the inflation forecasts. The next step of the research covers a qualitative analysis of IFT implementation. Finally, the existence of the interdependences of inflation forecast, optimal policy
\end{abstract}

(C) Copyright Institute of Economic Research \& Polish Economic Society Branch in Toruń Date of submission: March 16, 2015; date of acceptance: June 5, 2015

* Contact: magdalena.szyszko@wsb.poznan.pl, Wyższa Szkoła Bankowa w Poznaniu, al. Niepodległości 2, 61-874 Poznań, Poland; karolina.Tura@zie.pg.gda.pl, Politechnika Gdańska, ul. Narutowicza 11/12 80-233 Gdańsk, Poland

** The article presents the results of the research financed by the National Science Center: Interdependences of Inflation Forecasts and Inflation Expectations of Market Participants. Implications for the Central Banks, contract No. 2011/03/B/HS4/03705 and Forecasting Inflation on the Basis of DSGE Models in the Implementation of Inflation Targeting in Selected Central Banks, contract No. 2013/09/N/HS4/03766. 
paths and inflation expectations is analyzed. Credibility of the central bank, accuracy of the forecast and decision-making procedures focused on the forecast are the premises for the existence of relationship between forecasts and expectations. The research covers the period from July 2002 - till the end of 2013. Its methodology includes qualitative analysis of decision-making of the CNB, quantitative methods (Kia and Patron formula, MAE forecasts errors, quantification of expectations, non-parametric statistics). The results confirm the existence of interdependences between inflation forecasts and expectations of moderate strength. The preconditions of such interdependences are partially fulfilled. The research opens the field for cross-country comparisons and for quantification of IFT implementation.

\section{Introduction}

Modern monetary policy focuses on expectations. Central banks search for the tools that are helpful in shaping inflation expectations and that enhance their forward-looking attitude. Producing and revealing inflation forecast is such a tool. An ability to guide market expectations can be analyzed in the context of the central bank credibility. The central bank is credible when the private sector believes that the central bank will realize what it said (Mackiewicz-Łyziak, 2010, p. 12). The most obvious central bank's declaration is inflation target. When the market expectations are on the inflation target level, the central bank is perceived as credible. The article focuses on the central bank inflation forecasts and consumer expectations. They are analyzed jointly, and the context of inflation forecast accuracy and IFT implementation is added.

The main research question of this paper is whether households believe inflation forecasts. The hypothesis assumes that inflation forecasts published by CNB in the years 2002-2013 are accurate (1) and correlated with inflation expectations of households (2). The main objective of this research is to verify this hypothesis. The research has a broader context as well. Its starting point is the qualitative analysis of the inflation forecast targeting implementation and examination of the central bank's credibility. They constitute important preconditions of using forecasts for shaping expectations.

The research presented in the article is the first complex analysis of the inflation forecasts and their usefulness for the consumers and the central bank. 


\section{Theoretical Background}

Modern monetary policy is, and should be, forward-looking. The forwardlooking nature of inflation and monetary policy focus on inflation expectations are emphasized in modern monetary theory. Its framework is broadly described in the related literature (Mankiw, 1990, pp. 358-360, Goodfriend \& King, 1997, pp. 24-40, Galí, 2003, pp. 157-160). The starting point for developing a New Neoclassical Synthesis Model was the staggered price setting model (Calvo, 1983, pp. 384-393), where inflation depends on current inflation expectations and output gap. An expected price level change should be taken into account while readjusting prices, as the economic agents know that it may not be possible to change the prices in the following period. The ability of a central bank to influence expenditure, and hence pricing decisions, is strongly dependent upon its ability to influence market expectations regarding the future path of overnight interest rate, and not merely their current level (Woodford, 2003, p. 16).

The modern monetary policy strategy - inflation targeting - is believed to be the best way to implement a forward-looking, focused on expectations, monetary policy. Inflation forecast produced by the central bank on the basis of monetary transmission mechanism is immanent part of inflation targeting which can even become inflation forecast targeting (IFT), where inflation forecast plays the role of an intermediate objective of monetary policy. One argues that ascribing the function of an intermediate target to the inflation forecast simplifies implementing and monitoring monetary policy (Svensson, 1997, p. 1120).

The main reason why the forecasts are revealed is a need to shape inflation expectations of the public. Publishing the inflation forecast may help to guide longer-term expectations. It can serve as a temporary anchor, especially in situations where the target is missed because of shocks that are out of control of the central bank. An anticipated course of inflation, showed by a credible central bank may limit the expectations' growth (Skořepa \& Kotlán, 2003, pp. 154-155).

In the last decade majority of the central banks started to produce and reveal their own inflation (and GDP) forecast. It proves the importance of the forecast in monetary policy.

Inflation forecasts are made on different instrument-rate assumptions. The most important assumptions are: constant instrument rate during the entire forecast horizon (CIR), market expectations of the future interest rate (ME) and endogenous rate. These assumptions imply the different decisionmaking procedure (CIR - the rule of the thumb, endogenous rate - following optimal monetary policy path). Implementing the optimal monetary 
policy requires the optimal (specific) targeting rule related with a flexible strategy (target variables for both inflation and the output gap), and operating in a way that expresses the identity between the marginal rates of transformation (MRT) and substitution (MRS). MRS is based on the preferences of Monetary Policy Committee and MRT is based on the structure of the economy (Svensson, 2002, pp. 773-777). That is why the policy path includes the forecasts of the target variables such as inflation and output gap and instrument-rate path consistent with them. It can be described as the current and future interest rate path that is consistent with achieving inflation target (Svensson, 2003, pp. 451-460). In the research only the inflation forecasts are analysed and we assume that inaccurate forecasts imply inaccurate policy path.

\section{Methodology of the Research}

This research focuses on the case of the Czech Republic. The CNB has produced its own macroeconomic forecasts with endogenous interest rate since July 2002. It imposes the starting point of the research.

Table 1. Forecasting inflation in CNB

\begin{tabular}{|l|l|}
\hline Feature & Description \\
\hline DIT introduction & 1998 \\
\hline Forecast disclosure & from April 2001 \\
\hline Output & $\begin{array}{l}\text { forecast of inflation and GDP, fan chart (inflation, GDP, } \\
\text { policy path from 2008 and exchange rate path from 2009) }\end{array}$ \\
\hline Policy path & $\begin{array}{l}\text { from July 2002 given in descriptive way } \\
\text { form 2008 policy path disclosure on the fan chart }\end{array}$ \\
\hline Forecast frequency & $\begin{array}{l}\text { quarterly: January, April, July, October; } \\
\text { from 2008: February, May, August, November }\end{array}$ \\
\hline Forecast horizon & first, 6 quarters, then up to 8 quarters \\
\hline Transmission horizon & 4-6 quarters \\
\hline Main model & $\begin{array}{l}- \text { QPM: Quarterly Projection Model up to May 2008, } \\
\text { g3 from August 2008 }\end{array}$ \\
\hline $\begin{array}{l}\text { MPC in forecasting } \\
\text { procedure }\end{array}$ & discrete involvement \\
\hline
\end{tabular}

Source: own work. 
Forecasting inflation at the CNB occurs within the multi-model approach and its whole system is called FPAS. It consists of a vast number of models including auxiliary models, satellite models and one core model. The models support forecasting for different forecast horizons: short, medium and long term. The result of the forecasting procedure is a long-term projection of CPI inflation and, since 2008 also core inflation projection (MPRI). The components of the whole system are given in Table 2.

Table 2. The components of the FPAS

\begin{tabular}{|l|l|}
\hline Horizon & Type of model \\
\hline \multirow{2}{*}{ Short term } & Monitoring and Near-Term Forecasting Models \\
\cline { 2 - 2 } & Signal extractions models \\
\hline \multirow{2}{*}{$\begin{array}{l}\text { Medium } \\
\text { term }\end{array}$} & DSGE model g3 \\
\cline { 2 - 2 } Long term & Dynamic Optimizing Multisector Model with Stock-Flow Relationships \\
\hline
\end{tabular}

Source: own work.

The research on the inflation forecasts of the CNB is divided into four specific steps which are shown by Figure 1 .

Figure 1. Steps of the research

\begin{tabular}{l|c|}
$\begin{array}{l}\text { Step of the } \\
\text { research }\end{array}$ & Description \\
\cline { 2 - 2 } I & Credibility of central bank \\
II & Accuracy of the forecasts \\
III & $\begin{array}{c}\text { Analysis of the IFT } \\
\text { implementation }\end{array}$ \\
\hline IV & $\begin{array}{c}\text { Interdependences of } \\
\text { inflation forecasts and } \\
\text { inflation expectations of } \\
\text { consumers }\end{array}$ \\
\hline
\end{tabular}

\begin{tabular}{l} 
Research \\
tool \\
$\begin{array}{c}\text { Kia, Patron formula } \\
\text { Analysis of past inflation deviation } \\
\text { from the inflation target }\end{array}$ \\
\hline $\begin{array}{c}\text { Analysis of past inflation forecasts } \\
\text { deviation from the inflation target }\end{array}$ \\
\hline Qualitative analysis \\
\hline Non-parametric statistics for \\
forecasts and expectations \\
\hline
\end{tabular}

Source: own work. 
At the first stage, the credibility of the CNB is analyzed. The credibility is understood as the fulfillment the central bank's formal declaration - inflation target. This fulfillment was checked on the basis of calculating the mean absolute deviations of past inflation from the inflation target. The study includes two measures. The first one is a simple absolute deviation of inflation from the inflation target, as follows $|\dot{y}-\pi|$, where $\dot{y}$ is inflation rate and $\pi$ is the inflation target. The authors adopted their own interpretation of the deviations of the inflation from the inflation target. This interpretation assumes that the central bank is credible when the simple mean absolute past inflation deviation from the inflation target is in the range $<0,1>$. It is consistent with establishing a $+/-1$ p.p. fluctuation band around the inflation target. The next credibility measure is Kia and Patron formula (Kia \& Patron, 2004, p. 11) of inflation deviations from the inflation target: $\frac{100}{e^{0,5|\dot{y}-\pi|}}$. The use of the exponential function shows that with increasing deviation of inflation from the inflation target the credibility of central bank decreases exponentially (faster). The interpretation of credibility here is consistent with the previous measure. The deviation from the inflation target at 1 p.p implies the value of the formula close to 60,65 points. That is why the authors assume that the central bank is credible when the value of Kia and Patron formula is between 100 and 60 points. Figure 2 presents the possible values of Kia and Patron formula for the deviation between 0 and 10. Point A on the graph shows the bank's established credibility limit. The interpretation of the both measures is given in Table 3 .

Figure 2. Kia and Patron formula

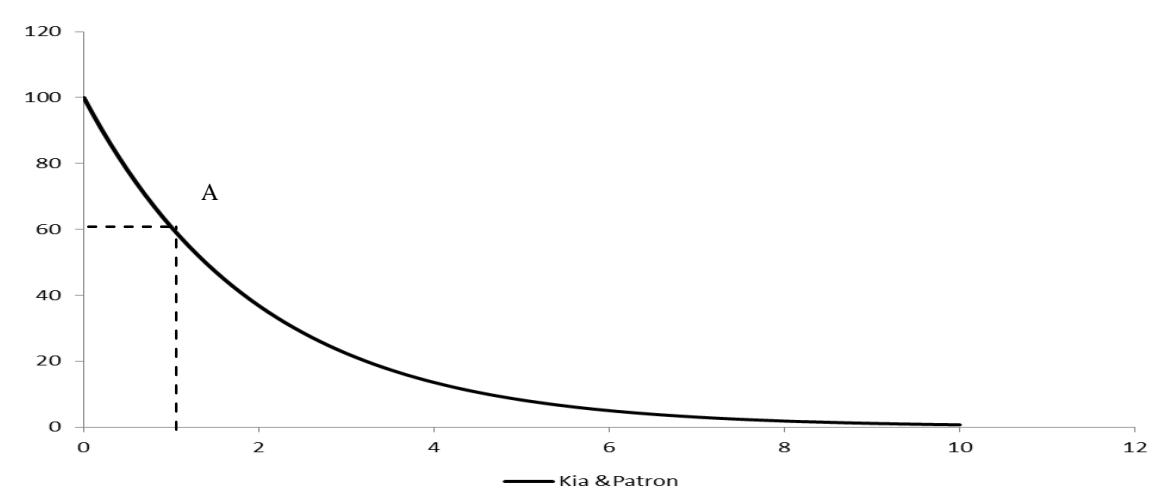

Source: own calculations. 
Table 3. Interpretations of simple mean absolute deviations of past inflation from the inflation target and the Kia and Patron formula

\begin{tabular}{|l|l|l|}
\hline $\begin{array}{c}\text { Mean absolute deviation inflation from } \\
\text { the inflation target during the year }\end{array}$ & $\begin{array}{c}\text { Kia and Patron } \\
\text { formula }\end{array}$ & Interpretation \\
\hline$\langle 0,1>$ & $<60 ; 100>$ & Credibility \\
\hline$>1$ & $60<$ & $\begin{array}{l}\text { Lack of credibil- } \\
\text { ity }\end{array}$ \\
\hline
\end{tabular}

Source: own work.

Accuracy of the forecasts is also based on two measures whose values and ideology are consistent with the previously chosen coefficients of credibility of central bank. The first measure is the absolute deviation of past inflation forecast from the inflation target: $|\hat{y}-\pi|$, where $\hat{y}$ is the inflation forecast. As the next step, the Forecast Absolute Error is calculated as follows $|\hat{y}-\dot{y}|$. The accurate inflation forecasts should be characterized by values smaller than 1 for both measures, which is described in Table 4.

Table 4. Interpretations of MAE and mean absolute deviation of past inflation forecast from the inflation target

\begin{tabular}{|l|l|l|}
\hline MAE & $\begin{array}{l}\text { Mean absolute deviation of the past inflation forecast } \\
\text { from the inflation target }\end{array}$ & Interpretation \\
\hline$<0,1\rangle$ & $\langle 0,1>$ & Accuracy \\
\hline$>1$ & $>1$ & \multirow{2}{*}{ Lack of accuracy } \\
\hline$>1$ & $<0,1>$ & \\
\hline$<0,1>$ & $>1$ & \\
\hline
\end{tabular}

Source: own work.

Besides the quantitative part of the research, qualitative analysis on the actual decision-making procedure of the CNB Board is made. Consistency of the Bank Board in IFT implementation can be a strong explanatory factor of the interdependences between the forecast and the inflation expectations. Analysis of the IFT implementation covers 4 factors (Szyszko, 2011, pp. 22-23):

- formal declaration on the importance of inflation forecasts,

- consistency of the decision of the Monetary Policy Committee (MPC) with the inflation forecast result,

- decision timing,

- decision justification. 
These factors show whether the forecasts of inflation or policy path constitute an important premise in decision-making of the CNB. If they do, the possibility of shaping expectations via inflation forecasts and policy path is enhanced.

Consistency of the decision of the Monetary Policy Committee with the inflation forecast result means that its decision is in line with forecasts message. This can be analyzed in two ways consistent with the way of coding inflation forecast message. The first way refers to the central path for inflation. The rule of thumb says here that whey the central path in the monetary policy horizon is above the target, the interest rates should be raised. When the projected inflation in the monetary policy horizon is below the target - the rates should be lowered. When the central path of projection is within the fluctuation band of the target, the MPC reaction (change of the interest rates or leaving them unchanged) is consistent with the IFT implementation. The central path of inflation at the targeted level means that the rates should be unchanged.

The second way refers to the interest rate path. Here the MPC decision is consistent with the forecast when the rates are changed according to the policy path suggestion. This is a more restrictive approach, as it does not open the room for maneuvers for the central bank. In the case of the Czech National Bank, it is more suitable to follow this way of analyzing the Bank Board decisions, as the Bank is producing unconditional forecast with endogenous policy path.

Decision timing shows whether the central bank perceives the forecast as the best information on the future state of the economy. If it does, it makes decisions consistent with the forecast message just after the forecast is made.

Decision justification shows the main rationale behind the decision on interest rates. The central bank sends the message on the importance of forecasts to the public if it refers to the forecast message in the justification.

The last part of the research focuses on interdependences of inflation forecasts and inflation expectations of consumers. The theory assumes that inflation should be an important factor in the formation of expectations. The research is limited to the correlation of both variables and it does not refer to the cause and effect relation. The research covers 46 forecasts (July 2002-2013). The way of coding the data on inflation forecasts and policy path is described in Table 5. 
Table 5. Inflation forecast and policy path

\begin{tabular}{|l|l|l|}
\hline Forecast of: & \multicolumn{1}{c|}{ Options: } & \multicolumn{1}{c|}{ Timing } \\
\hline & $\begin{array}{l}\text { - the central path is below the lower boundary of } \\
\text { fluctuation band, } \\
\text { - the central path t is below the inflation target but } \\
\text { within the fluctuation band; } \\
\text { Central path }\end{array}$ & $\begin{array}{l}\text { Beginning of } \\
\text { it is at the inflation target level; } \\
\text { of inflation } \\
\text { - it is above the inflation target but within the fluctu- } \\
\text { ation band; } \\
\text { horizon }\end{array}$ \\
& $\begin{array}{l}\text { - the central path is above the upper boundary of } \\
\text { fluctuation band }\end{array}$ & \\
\hline $\begin{array}{l}\text { Interest } \\
\text { rates path }\end{array}$ & $\begin{array}{l}\text { - the rates are to be lowered; } \\
\text { - the rates are to stay unchanged; } \\
\text { - the rates are to be raised. }\end{array}$ & $\begin{array}{l}\text { First step - just } \\
\text { after producing } \\
\text { forecast }\end{array}$ \\
\hline
\end{tabular}

Source: own work.

The inflation forecast here means not only the central projected path of inflation but the whole policy path as well. This is consistent with the Czech forecasting system. The forecast itself is unconditional - policy path is endogenous. This means that the central path of inflation should be on the inflation targeted level within the monetary policy horizon if the interest rates are changed according to the path. In reality this condition is not fulfilled, as the model does not capture future shocks and the rates are not changed in the way suggested by the path in next steps (they are actualized with the next forecast). This is why both outcomes of the model - central path of inflation and interest rates path - are confronted with inflation expectations of consumers.

The data on inflation forecast are encoded because of two reasons. First of all, consumer's inflation expectations are considered. Consumers are not specialists. They do not read the forecasts on their own. They do not understand sophisticated information on inflation forecasts. It is enough to say that qualitative surveys on expectations were abandoned by the central banks, as the households awareness of economic situation was poor, and the results of surveys were not reliable. The second reason for encoding the data is connected with the way the forecast is revealed. No detailed information on levels was given at the beginning of the research period. Forecast and the policy path were presented in the Inflation Report in a descriptive way'.

As the forecast is produced quarterly and the expectations are examined monthly, the research assumes that one forecast message may influence the

\footnotetext{
${ }^{1}$ For central path of inflation the standard correlation measure is also calculated.
} 
expectations formation 3 times. The lags are also assumed: the forecast may influence expectations in the month of its disclosure as well as during the following months.

Consumers' expectations of households are not directly observed. They are examined on the basis of regular qualitative surveys. Consumers answer the question on their inflation perception and expectations. Inflation perception refers to the past inflation and is not the subject of this research.

The question for inflation expectations is: By comparison with the past 12 months, how do you expect that consumer prices will develop in the next 12 months? And the answers to choose from: They will...increase more rapidly, increase at the same rate, increase at a slower rate, stay about the same, fall, don't know (The Joint Harmonized..., 2007, p. 51). Then the answers can be used in two ways. First of all, the balance of answers is calculated. The balance of answers does not directly measure the inflation expectations, thus it cannot be interpreted in a straightforward way. For example, when it is positive it means that the number of respondents who expected prices to increase more rapidly over the next 12 months than in the past exceeded the number of those who expected prices to remain the same or increase more slowly that in the past. (The Joint Harmonized..., 2007, p. 18).

The answers to the surveys' question on expected inflation are also the basis for quantifying inflation expectations using the adjusted Carlson-Parkin method. It assumes that if the number of respondents is sufficiently large, the expected rate of price change is normally distributed ${ }^{2}$. The quantification of qualitative responses makes use of the fact that, in replying to the survey question regarding inflation expectations, respondents compare their predictions with the rate of price change as perceived when the survey is carried out (Łyziak, 2003, pp. 11-13). The latest inflation figure stays here for inflation perception.

Survey data on expected inflation are derived from the Business and Consumers Surveys - The European Commission survey on business and household situation. Surveys are held monthly. The Czech Republic has been covered from 1995.

The interdependences between inflation forecast (interest rate path) and expectations are calculated here. Non-parametric correlation measures are used. This is imposed by the range of data availability. The Pearson's correlation of the central path of inflation and the expectations is also tested.

\footnotetext{
${ }^{2}$ Assumption of normal distribution of inflation expectations is the oldest and the most common approach in the empirical research. That is why the authors decided to use it. However, there are some reasons to presume that this distribution is asymmetric, more precisely skewed to the right (Berg, 2001, p. 90).
} 
However, due to limited consumers' perception of economic data, coded results are more important.

\section{Results of the Empirical Research}

At the first stage of the research the authors analyzed the credibility of the CNB in the years 2002-2013. The study was conducted on monthly data. The formation of the values for CNB of Kia and Patron formula are presented by Figure 3.

According to the results, the lack of credibility occurred temporarily in five periods: in mid-2002, in the year 2003 and in the first two months of 2004, in mid-2010, at the end of 2002. In other periods CNB can be described as credible. The mean value of Kia and Patrol formula is 65,46 points.

The analysis of past inflation deviations from the inflation target, due to similar construction, gave the same results, which allowed the authors to confirm the thesis that in the years 2002-2013 CNB was credible. The summary of this step of the research is presented in Table 6 .

Figure 3. The formation of the values of Kia and Patron formula in CNB in years 2002-2013

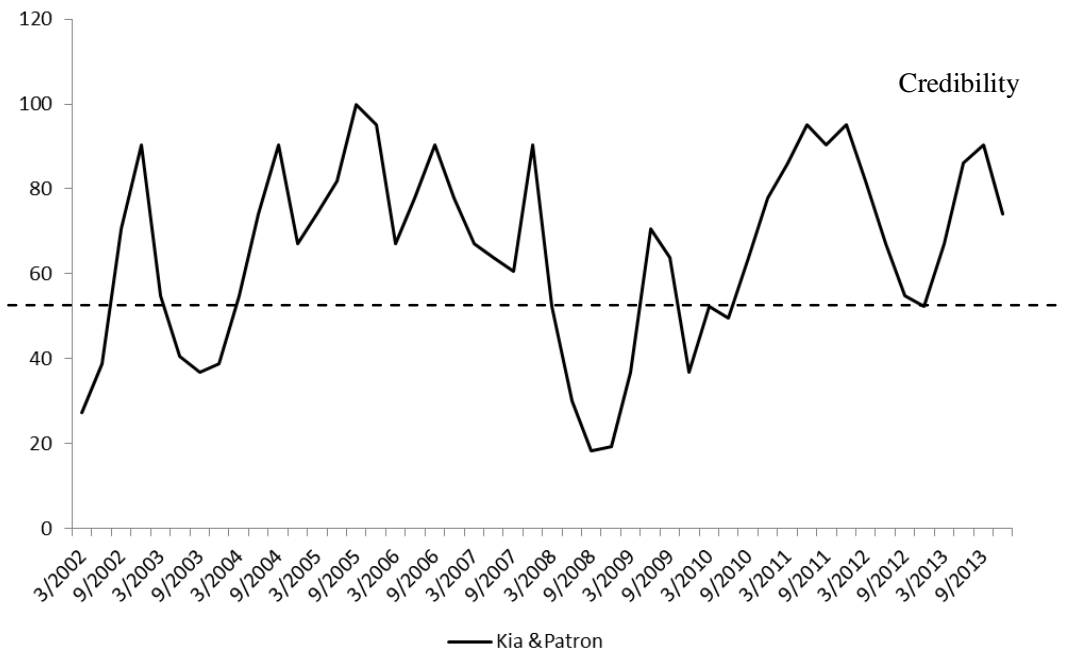

Source: own calculations based on ARAD database. 
Table 6. Interpretations of a simple mean absolute deviation of past inflation from the inflation target and the Kia and Patron formula in CNB in years 2002-2013

\begin{tabular}{|l|l|l|}
\hline $\begin{array}{l}\text { Mean absolute deviation inflation } \\
\text { from the inflation target }\end{array}$ & $\begin{array}{l}\text { Mean value of Kia and } \\
\text { Patron formula }\end{array}$ & Interpretation \\
\hline 0,98 & 65,46 & Credibility \\
\hline
\end{tabular}

Source: own work.

As the CNB during the research period was credible, the information produced by the bank could be the premise in expectations shaping of consumers.

The next step of the research focuses on the forecasts accuracy. According to the idea of optimal policy, the inflation forecast is consistent with the instrument-rate forecast and at the end of the horizon it should be equal to the inflation target. That is why it is important to check how to evaluate the inflation forecasts in relation to the inflation target. At this step of the research the authors analyzed the mean absolute past inflation forecasts deviation from the inflation target in CNB from July 2002 to May 2012 (the period of the study was chosen due to available data). The research was conducted on quarterly data. The value of the mean absolute deviations of past inflation forecasts from the inflation target is $1,31 \%$. The next part of the analysis of inflation forecasts was calculation the absolute forecasts errors. The value of the mean absolute forecasts error (MAE) of the inflation forecasts is $1,07 \%$. The results show that inflation forecasts published by CNB in the chosen period were inaccurate. The summary of this step of the research is presented in Table 7.

Table 7. Interpretations of MAE and mean absolute deviation of past inflation forecast from the inflation target in $\mathrm{CNB}$

\begin{tabular}{|l|l|l|}
\hline MAE & $\begin{array}{c}\text { Mean absolute deviation of the past inflation forecast from } \\
\text { the inflation target }\end{array}$ & Interpretation \\
\hline 1,31 & 1,07 & $\begin{array}{l}\text { Lack of accura- } \\
\text { cy }\end{array}$ \\
\hline
\end{tabular}

Source: own work.

The results of the first and the second part of the research create a background for the analysis of interdependences of expectations and forecasts results. The CNB in the period covered by the examination was credible, which is the first step to properly anchor the inflation expectations. Unfor- 
tunately, the results also show that the CNB inflation forecasts in the same period were not accurate and were not a good forecast in the sense of predicting future inflation. On the other hand, the value of the mean deviation from the inflation target (which is 1,07\%) implies that the forecasts did not deviate strongly from the inflation target. That is why the forecasts can still be seen as a useful tool, according to IFT ideology.

Table 8. The CNB decisions' deviations

\begin{tabular}{|l|l|}
\hline \multicolumn{1}{|c|}{ Time } & \multicolumn{1}{c|}{ Deviation explanation } \\
\hline IR April 2003 & Wrong assumption on the timing of direct taxes change. \\
\hline IR October 2004 & $\begin{array}{l}\text { The signs of inflation pressure were not unambiguous; the } \\
\text { Board assessed monetary conditions as restrictive enough. }\end{array}$ \\
\hline IR January 2006 & $\begin{array}{l}\text { Appreciation of CZK tightened monetary conditions far } \\
\text { enough. }\end{array}$ \\
\cline { 1 - 2 } IR October 2006 & Asymmetric risk of lower inflation. \\
\cline { 1 - 2 } IR November 2011 & Persisting effect of VAT rise. \\
\cline { 1 - 1 } IR February 2013 & $\begin{array}{l}\text { Main rate of the CNB at the level 0.05\% (technical zero). } \\
\text { strument: FX market interventions. }\end{array}$ \\
\cline { 1 - 2 } IR May 2013 & \\
\cline { 1 - 2 } IR August 2013 & \\
\hline IR November 2013 &
\end{tabular}

Source: own work based on data and information from Inflation Reports and Statements of CNB Board published by CNB in years 2002-2013.

The third step of the research focuses on IFT implementation in the CNB. The CNB shows strong commitment to IFT implementation. It starts on the declarations level - the forecast is claimed to be of greatest relevance in decision-making (which is declared at the website of the Bank and in its strategic documents). This declaration meets the practice of the Bank Board as it changes rates accordingly to the message of forecast and does it when the forecast has just been produced. In the examined period (114 meetings of the Bank Board, 46 forecasts discussed) only 9 times the Board ignored the message of forecasts (in terms of interest path). These cases are called decision's deviations. The details of the explanations are given below. They are divided into two groups (presented in Table 8). The first one covers deviations from 2003 to 2011. Their rationale is shock or "wait and see" attitude of the CNB. The second group covers 2013. The reason for not following the message was technical - the Bank had been already operating at the nominal zero rate. The Board announced the possibility of intervention on the FX market to weaken the Czech koruna. The message of the forecast was ignored because it was not possible to follow it. The methodology of analysis is clear and classifies these cases as decisions' devia- 
tions. Except those special situations, the CNB followed the interest path consistent with its macroeconomic forecast. Even in the most turbulent period of the end of 2008 and 2009, the Board's decisions were in line with the forecast path of interest rates. The precondition of using inflation forecasts as the tool that supports expectations shaping is thus fulfilled.

Figure 4 that presents the measures of the forecast accuracy also contains the information on the compatibility of the Bank Board decisions with IFT. It shows that inflation forecasts played a role of intermediate target in $\mathrm{CNB}$, even though most of them were inaccurate.

Figure 4. Accuracy of the inflation forecasts and their compatibility with IFT procedure in $\mathrm{CNB}$

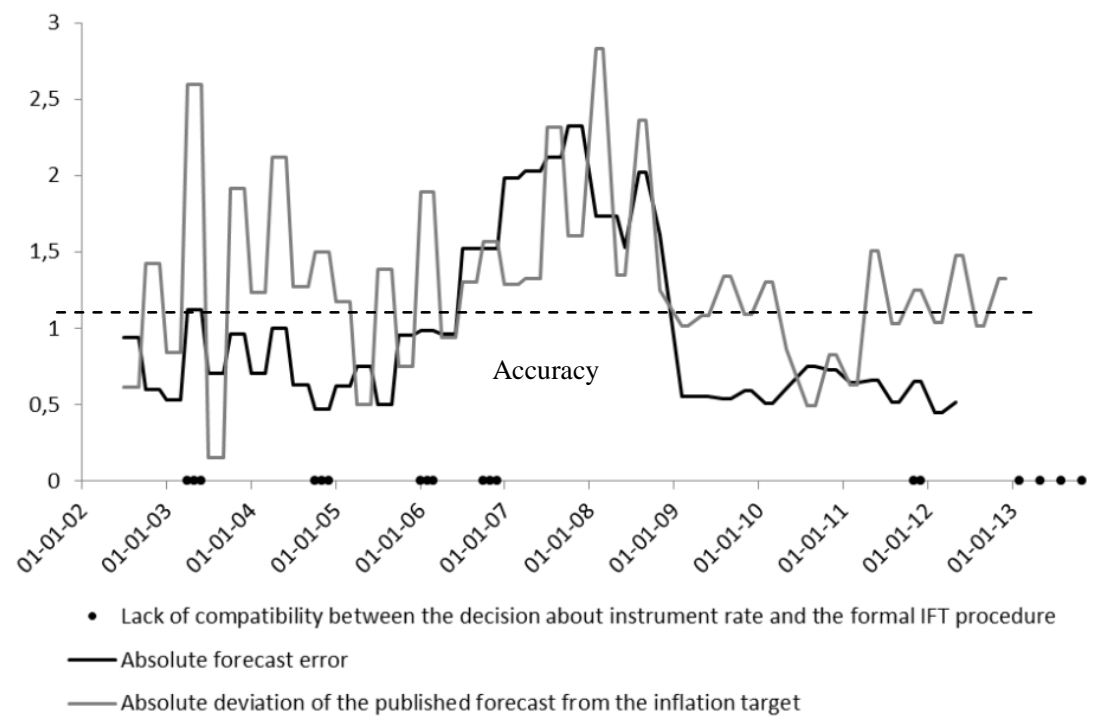

Source: own calculations based on ARAD database, data and information from Inflation Reports and Statements of CNB Board published by CNB in years 2002-2013 and data obtained from bank employees.

The results of the research on interdependences between expectations and forecasts results are presented in Table 9. They prove the existence of statistically important (for $\mathrm{p}=0,05$ ) interdependences of inflation forecast and expectations. Their strength is moderate and it rises with the lengthening of the lag. For the inflation forecast the results of non-parametric statistics are also confronted with the standard correlation measure (for quantified inflation forecast) that confirms the results for the coded data. 
Table 9. Interdependences of forecasts and expectations 2002-2013

\begin{tabular}{|c|c|c|c|c|c|}
\hline Variables & Lag & Spearman & Gamma & Kendall & Pearson \\
\hline \multirow{4}{*}{ CP/Exp } & $\mathrm{T}$ & 0.376495 & 0.295921 & 0.252755 & 0.348916 \\
\hline & $(\mathrm{t}+1)$ & 0.393286 & 0.332547 & 0.284073 & 0.416075 \\
\hline & $(t+2)$ & 0.404410 & 0.363186 & 0.310355 & 0.462181 \\
\hline & $(\mathrm{t}+3)$ & 0.417596 & 0.391468 & 0.334523 & 0.491205 \\
\hline \multirow{4}{*}{ PP/Exp } & $\mathrm{T}$ & 0.445988 & 0.449153 & 0.361885 & \\
\hline & $(t+1)$ & 0.480176 & 0.479140 & 0.386046 & \\
\hline & $(\mathrm{t}+2)$ & 0.508132 & 0.503340 & 0.405611 & \\
\hline & $(\mathrm{t}+3)$ & 0.533420 & 0.525081 & 0.423338 & \\
\hline
\end{tabular}

Source: own calculations based on data and information from Inflation Reports published by CNB in years 2002-2013.

The results concerning the central path (here referred to as $\mathrm{CP}$ - central path of inflation) are not surprising. If the forecasts showed that inflation would exceed the goal, the expectations rose.

However, the results on interest path (PP - policy path) are counterintuitive. They show that when the rise of the rates is consistent with the macroeconomic forecast, the expectations of consumers rise as well. Transmission mechanism based on the modern theory draws a negative correlation of interests rates and expectations. The results obtained for the CNB show that the forecast itself guides expectations rather than policy path.

The results of examination of the interdependences and the CNB's decision making procedure may not be interpreted unambiguously. First of all, a positive correlation of policy path and expectations of consumers is surprising. Secondly, the strength of interdependences is moderate. The forecast is not the only one factor influencing expectations. A possible explanation of moderate strength (instead of strong relationship) is inaccuracy of the forecasts. Thirdly, the existence of positive relationships between inflation forecast and expectations proves that consumers do not really perceive that the central bank is effective in its actions. In the case of perfect credibility, inflation expectations are on the target level.

In the years 2002-2013 the CNB could be characterized as a credible central bank, however its credibility was not perfect. The CNB forecasts were inaccurate. It is sure that this non perfect credibility and inaccuracy of the forecast has an impact on interdependences. It must also be remembered that CNB is implementing a flexible type of IFT. That is why accomplishment of other target variables (like output gap) could be carried out at the expense of the accuracy of inflation forecasts. 
It should be mentioned that the research was held for consumers - a less educated group in the economy (as compared with specialists and companies). This is why the unambiguous results appears.

\section{Conclusions}

In perfect situation, the perfectly credible central bank publishes accurate forecasts which anchor the economic agents' inflation expectations on the target level of inflation. The CNB is not perfectly credible and it publishes inaccurate forecasts - according to methodology of the research. However, those forecasts play the role of intermediate target of monetary policy. They are also correlated with inflation expectations of consumers. The results of the research are far away from perfect situation but they are satisfactory. Anchoring inflation expectations is the main function of inflation forecasts in the central banks implementing inflation targeting strategy. From this point of view, inflation forecasts of the CNB fulfill, at least to some extent, the main goal of revealing them - they are correlated with inflation expectations. The research confirms the main body of the hypothesis that inflation forecasts published by CNB in the years 2002-2013 were correlated with inflation expectations of households, regardless of the fact that the hypothesis of the forecast accuracy is rejected. The problem is connected with the forecasting system (that produces inaccurate forecasts), while the other results are consistent: credible central bank that implements IFT may affect expectations via forecasts.

There are several directions of further research. The most obvious is expanding the scope of the research on the other central banks. Such a comparative analysis can be enriched with the countries of the longest experience in inflation forecast targeting. Having the panel of countries that implement IFT and their forecast-expectations interdependences, further questions on the results can be answered:

- Does the strength of correlation depend on consistency in IFT implementation?

- Does the strength of correlation depend on the forecasts accuracy?

- Do the interdependences depend on the credibility of the central bank and its effectiveness?

- Does the transparency of the central bank influence the relationship of the expectations and the forecast results?

The field for methodological improvement also exists in this kind of research: the data on forecast results may be encoded in a different way. 
In this research the authors analyzed the credibility of central bank, inflation forecast accuracy and interdependences of the forecasts and inflation expectations. Steps of the study were designed to preserve the consistency with theoretical premises. The obtained results for subsequent steps of the research correspond with each other. The results, along with a qualitative assessment of the use of forecasts, describes the idea of IFT implementation at the CNB. The results are a contribution to the creation of complex index specifying the degree of implementation of the IFT strategy in central banks.

Regardless of the future expansion of the research, the results obtained here deliver valuable information on the function of the forecasts.

\section{References}

Berg, J. M. (2001). The Preparation of Monetary Policy: Essays on a Multi-Model Approach. Boston: Springer Science, Business Media Dordrecht. http://dx.doi.org/10.1007/978-1-4757-3405-8.

Calvo, G. (1983). Staggered Prices in Utility-Maximizing Frameworks. Journal of Monetary Economics. 12.

Galí, J. (2003). New Perspective on Monetary Policy. Inflation and Business Cycles. Advances in Economics and Econometrics, Theory and Applications. Eighth World Congress, 3. http://dx.doi.org/10.1017/CBO9780511610 264.007.

Goodfriend, M., \& King, R. G., (1998). The New Neoclassical Synthesis and the Role of Monetary Policy. Working Paper No. 5, Federal Reserve Bank of Richmond, Richmond. http://dx.doi.org/10.2307/3585232.

Kia, A. Patron, H. (2004). Market-Based Monetary Policy Transparency Index, Risk and Volatility - The Case of the United States. Carleton Economic Papers, $7 / 2004$.

Łyziak, T. (2000). Consumer Inflation Expectations in Poland, ECB Working Paper Series, Working Paper no. 287.

Mackiewicz-Łyziak, J. (2010). Wiarygodność Banku Centralnego, Difin, Warszawa.

Mankiw, N.G. (1990). A Quick Refresher Course in Macroeconomics. Journal of Economic Literature, 28, December.

Skořepa, M., \& Kotlán, V. (2003). Assessing Future Inflation in Inflation Targeting: Forecasts or Simulations. Monetary Policy in Changing Environment, 19.

Svensson, L. E. O. (1997). Inflation Forecast Targeting: Implementing and Monitoring Inflation Targets. European Economic Review, 41(6). http://dx.doi.org/10.1016/S0014-2921(96)00055-4.

Svensson, L. E. O. (2002). Inflation Targeting: Should it be Modeled as an Instrument Rule or a Targeting Rule? European Economic Review, 46(4-5). http://dx.doi.org/10.1016/S0014-2921(01)00212-4. 
Svensson, L. E. O. (2003). What is wrong with Taylor Rules? Using Judgment in Monetary Policy through Targeting Rules. Journal of Economic Literature, 42(2). http://dx.doi.org/10.1257/002205103765762734.

Svensson, L. E. O, (2005). Optimal Policy Projections. International Journal of Central Banking, 1(1), http://dx.doi.org/10.2139/ssrn.813284.

Szyszko, M. (2011). The interdependences of central bank's forecasts and economic agents inflation expectations. Empirical study, National Bank of Poland Working Papers, No. 115, Warsaw. http://dx.doi.org/10.2139/ssrn.2006341.

Szyszko, M. (2013). The Interdependences of Central Bank's Forecasts and Inflation Expectations of Consumers. Bank i kredyt, 44(1).

Tura, K. (2012). Prognozowanie inflacji $w$ Polsce $w$ latach 1999-2009 $w$ ramach modeli budowanych w Narodowym Banku Polskim na potrzeby realizacji kryterium celu inflacyjnego. Materiały i Studia Narodowego Banku Polskiego, No. 279.

Woodford, M (2003). Interest and Prices. Foundations of Theory of Monetary Policy, Princeton University Press, 2003.

The Joint Harmonized EU Programme of Business and Consumer Surveys, User Guide, (2007). European Commission. 